\title{
Oil and Fatty Acid Contents of White Sorghum Varieties under Soaking, Cooking, Germination and Fermentation Processing for Improving Cereal Quality
}

\author{
Abd El-Moneim M.R. AFIFY' ${ }^{1}$, Hossam S. EL-BELTAGI ${ }^{1,2 *}$, \\ Samiha M. ABD EL-SALAM ${ }^{3}$, Azza A. OMRAN ${ }^{3}$ \\ ${ }^{1}$ Department of Biochemistry, Faculty of Agriculture, Cairo University, P. Box 12613, Gamma St, Giza, Cairo, Egypt \\ ${ }^{2}$ Vice-Rectorate for Graduate Studies and Research, SUDLS, King Saudi University, Riyadh \\ 11451, Kingdom of Saudi Arabia; lbltg@yahoo.com (* correspondingauthor) \\ ${ }^{3}$ Department of Crops Technology, Food Technology Research Institute, Agricultural Research Center, Egypt
}

\begin{abstract}
The changes in lipid and fatty acid contents after soaking, cooking, germination and fermentation of three white sorghum varieties were studied to improve cereal quality. The results revealed that oil in raw sorghum varieties ranged from 3.58 to $3.91 \%$, respectively and 'Dorado' represents the highest variety in oil content. As general trend after germination, oil content was decreased. Fatty acid contents of raw sorghum contains palmitic ( 12.10 to $13.41 \%$ ), palmitoleic $(0.47$ to $1.31 \%$ ), stearic ( 1.13 to $1.36 \%$ ), oleic (33.64 to $40.35 \%)$, linoleic ( 42.33 to $49.94 \%)$, linolenic (1.53 to $1.72 \%$ ), arachidic ( 0.10 to $0.18 \%)$ and eicosenoic acid ( 0.24 to $0.39 \%$ of total lipid). 'Dorado' was the highest variety in oleic acid while 'Shandaweel- 6 was the highest variety in palmitic, stearic, linolenic, arachidic, eicosenoic acid and total saturated fatty acids. 'Giza-15' was the highest variety in palmitoleic, linoleic, total unsaturated fatty acids and ratio of unsaturated to saturated fatty acids. Fatty acids relative percentage changed after soaking, cooking, germination and fermentation.
\end{abstract}

Keywords: cooking, fatty acid, fermentation, germination, oils, soaking, sorghum

\section{Introduction}

One of the important facts of cereal crops is their diverse pool of fatty acids. The oil seeds contains particular fatty acids with industrially important because of their characteristic properties. The main constituent of all the oils is the fatty acids which may include saturated fatty acids (SFA), monounsaturated fatty acid (MUFA) and polyunsaturated fatty acid (PUFA) that contribute in human physiology in different ways. PUFAs are present as component of membrane phospholipids in specific tissue or a precursor of hormone like prostaglandins (Patil and Gislerod, 2006).

Sorghum (Sorghum bicolor [L.] Moench) one of the most important weaning foods in low-income and highincome countries (Abdel-Rahim and El-Beltagi, 2010; Lonnerdal, 2000; Shallan et al., 2010a; Shallan et al., 2010b; Shehab et al., 2010). It ranks fifth among the world cereals, following wheat, maize, rice and barley in production area and total production. Sorghum is an extremely important crop in Asia, Africa and other semi-arid regions of the world (Dillon et al., 20007).

The nutrient composition of sorghum indicates that it is a good source of energy, proteins, carbohydrates, vitamins and minerals (Afify et al., 2011a, 2012a, 2012b;
Dicko et al., 2006). Sorghum contains good quality proteins are those that are readily digestible and contain the essential amino acids in quantities that correspond to human requirements (Afify et al., 2011b; El-Beltagi and Mohamed, 2010; El-Beltagi, 2011; El-Beltagi et al., 2011a; 2011b; Zhao et al., 2008).

Sorghum contains rather low levels of total oils (3.20$3.90 \%$ ), with most occurring in the germ fraction (Morrison, 1978). Oleic and linoleic acids are $84 \%$ of the total fatty acids, making the lipids highly unsaturated (Hoseney et al., 1981).

Sorghum, which is characterized by a relatively high concentration of fatty acids, which exceeds that of other competing cereals like barley, wheat and millet (Osagie, 1987; Matz, 1991; Palmer et al., 1987; Shallenbcrger, 1971).

Most of the sorghum varieties polyunsaturated fatty acids were higher than monounsaturated fatty acids (Mehmood et al., 2008). Sorghum bicolor varieties could be additional sources of edible oil due to presence of clinically important saturated and high concentration of unsaturated fatty acids.

The objective of this study was to investigate the changes in oils and fatty acids after soaking, cooking, germina- 
tion and fermentation of three white sorghum varieties and make attention of sorghum as a source of edible oil.

\section{Materials and methods}

\section{Samples and chemicals}

Three white sorghum varieties (Sorghum bicolor L. Moench), were obtained from the Crops Research Institute, Agricultural Research Center for 'Shandaweel-6', and from Central Administration for Seed Certification (CASC), Ministry of Agriculture and Land Reclamation, Giza, Egypt for 'Dorado' and 'Giza-15'. The grains were carefully cleaned and freed from broken grains and extraneous matter.

Fatty acids were obtained from Sigma-Aldrich Chemical Co., St. Louis, USA. All other chemicals used were of analytical reagent grade.

\section{Treatments}

For soaking, sorghum grains were soaked in distilled water for $20 \mathrm{~h}$ with a ratio $1: 5 \mathrm{w} / \mathrm{v}$ and the soaked water changed twice. At the end of soaking period, the soaked water was discarded. The grins were rinsed twice with distilled water and the grains were dried in oven at $45 \pm 5^{\circ} \mathrm{C}$.

For germination, soaked grains were germinated, placed in plastic boxes, covered with cotton cloth and left at room temperature for $72 \mathrm{~h}$, and then the grains were dried. The root and shoot portions were manually removed. The grains were milled into fine flour and kept until analysis (Fig. 1).

For fermentation, sorghum flour which obtained from dried soaked grains was cooked by boiling with sufficient amount of distilled water for $10 \mathrm{~min}$. Then the obtained slurry were dried, milled and kept until analysis as shown in (Fig. 1).

\section{Determination of total oils}

Oils content of raw sorghum and treatments were determined according to the methods of AOAC (2000).

\section{Fatty acid determination}

Sorghum oil was extracted by hexane and fatty acids were analyzed by Agilent HP 6890 capillary gas chromatography and reported in relative area percentages. The methyl esters of fatty acids were prepared according to the method of Glass (1971). A solution of oil (ca. $0.1 \mathrm{~g})$ in hexane $(2 \mathrm{ml})$ was mixed with methanolic potassium hydroxide $(0.2 \mathrm{ml}, 2 \mathrm{~N})$ by shaking vigorously for $30 \mathrm{sec}$. Upper layer was decanted which contains the methylester. The hexane layer was suitable for injection into the gas chromatograph. The fatty acid methyl esters were identified using a gas chromatograph equipped with dual flame ionization detector was used. The fractions of fatty acid methyl esters were conducted using a DB-23 capillary-coiled glass column $(60 \mathrm{~m} \times 0.32 \mathrm{~mm} \times 0.25 \mu \mathrm{m})$. The initially oven temperature was $150^{\circ} \mathrm{C}$, nitrogen gas was used as a carrier $3 \mathrm{ml} / \mathrm{min}$, the flow rates for hydrogen and air were $40 \mathrm{ml} /$ $\mathrm{min}$ and $450 \mathrm{ml} / \mathrm{min}$, respectively and the temperature of injector and detector were $230^{\circ} \mathrm{C}$ and $250^{\circ} \mathrm{C}$, respectively. The fatty acid methyl esters were identified by comparison their retention times with known fatty acid standard mixture. Peak areas were automatically computed by an integrator. The fatty acid composition was expressed as percentage of total fatty acids.

\section{Sorghum grains}

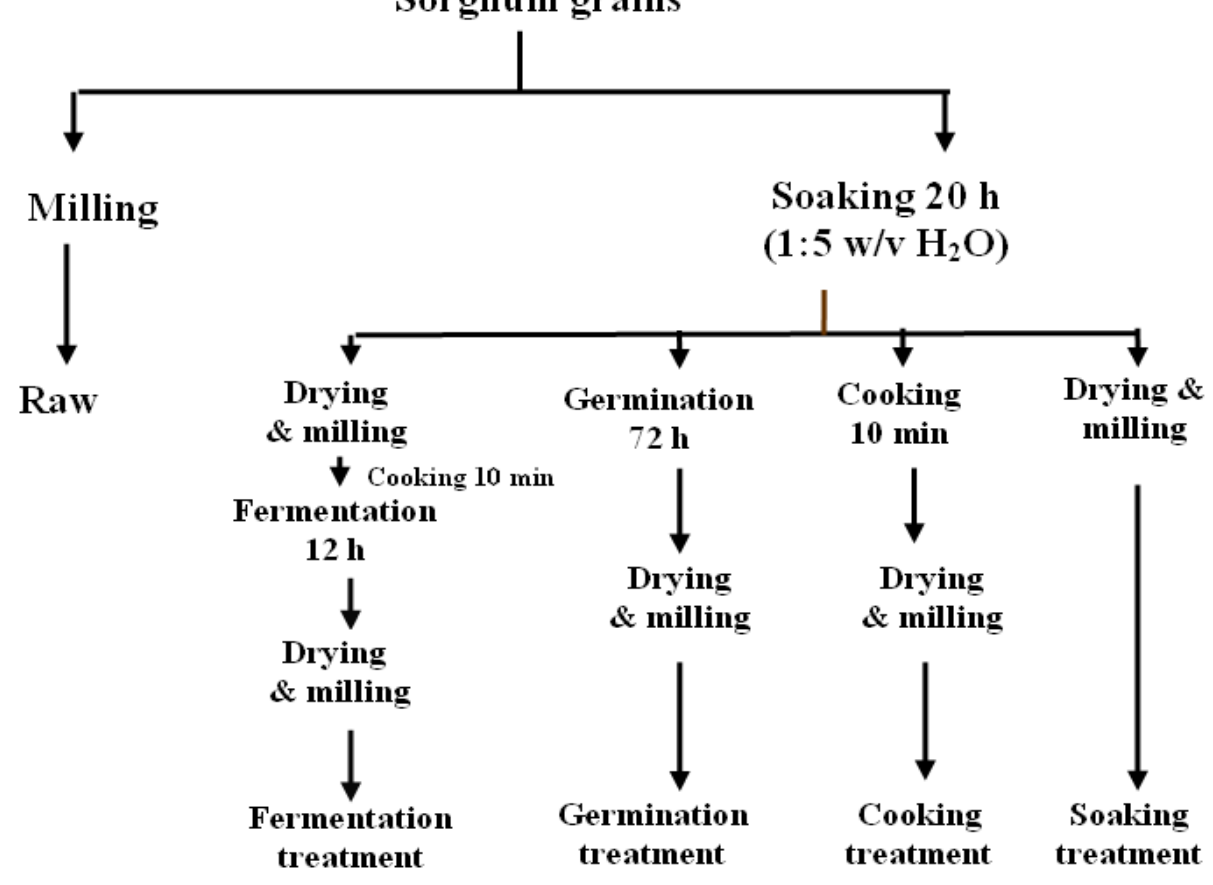

Fig. 1. Flow chart for the different treatments of sorghum grains 
88

\section{Statistical analysis}

For the analytical data, mean values and standard deviation are reported. The data obtained were subjected to one-way analysis of variance (ANOVA) and least significant difference (LSD) at $p<0.05$.

\section{Results and discussion}

\section{Oils content of sorghum at different treatments}

Tab. 1 presents oils content of sorghum after soaking, cooking, germination and fermentation. Oil content ranged from 3.58 to $3.91 \%$ in raw sorghum and 'Dorado' variety represents the highest value. Sorghum contains 3.39-3.62\% and 3.23-3.78\%, oil in Sudan and Korea respectively while in Nigeria sorghum had $3.90 \%$ oil (Adeyeye and Ajewole, 1992; Chung et al., 2011; Hamad, 2007).

Oil contents were significantly decreased after different treatments except for soaking treatment which non-significantly increased. Results are in agreement with Okrah (2008), who found that oil content of germinated sorghum varied from 1.44-2.57\%, while in other study; soaking and fermentation reduce oil content (El Maki et al., 2007). The reduction may be due to the fact that biochemical and physiological changes occurred during germination; such changes require energy to proceed, and therefore part of the seed oil was utilized for the production of this energy. Germination and cooking processes caused significant de-

Tab. 1. Oil contents of sorghum at different treatments $(\% \text { on } \mathrm{DW})^{*}$

\begin{tabular}{|c|c|}
\hline Treatment & Oil \\
\hline \multicolumn{2}{|c|}{ Raw } \\
\hline 'Dorado' & $3.91 \pm 0.25^{\mathrm{ab}}$ \\
\hline 'Shandaweel-6' & $3.66 \pm 0.15^{b c}$ \\
\hline 'Giza-15’ & $3.58 \pm 0.22^{c}$ \\
\hline \multicolumn{2}{|c|}{ Soaking } \\
\hline 'Dorado' & $4.10 \pm 0.27^{a}$ \\
\hline 'Shandaweel-6' & $3.78 \pm 0.01^{b c}$ \\
\hline 'Giza-15’' & $3.53 \pm 0.22^{c}$ \\
\hline \multicolumn{2}{|c|}{ Cooking } \\
\hline 'Dorado' & $2.13 \pm 0.05^{\mathrm{c}}$ \\
\hline 'Shandaweel-6' & $2.46 \pm 0.05^{\mathrm{d}}$ \\
\hline 'Giza-15' & $2.31 \pm 0.21^{\mathrm{de}}$ \\
\hline \multicolumn{2}{|c|}{ Germination } \\
\hline 'Dorado' & $1.70 \pm 0.09^{\mathrm{f}}$ \\
\hline 'Shandaweel-6' & $2.28 \pm 0.11^{\mathrm{dc}}$ \\
\hline 'Giza-15’ & $1.66 \pm 0.04^{\mathrm{f}}$ \\
\hline \multicolumn{2}{|c|}{ Fermentation } \\
\hline 'Dorado' & $1.39 \pm 0.04^{\mathrm{g}}$ \\
\hline 'Shandaweel-6' & $1.36 \pm 0.03^{g}$ \\
\hline 'Giza-15' & $1.25^{\mathrm{g}} \pm 0.03$ \\
\hline LSD & 0.2555 \\
\hline
\end{tabular}

${ }^{*} \mathrm{DW}$ basis $=$ dry weight basis.. Values are mean of three replicates $\pm \mathrm{SD}$, number in the same column followed by the same letter are not significantly different at $p<0.05$ level. LDS = Least Significant Difference creases in oil content (Mubarak, 2005). Sorghum oil was significantly decreased after fermentation which improves the bioavailability of iron and zinc during soaking and germination of three white sorghum varieties (Afify et al., 2011a; Alemu, 2009). On the same time fennel were germinated on Murashige and Skoog medium (MS) without plant growth regulators reduce the amount of estragole (not favorite for Human consumption) and increase the amount of trans-anethole (Afify et al., 2011c).

\section{Sorghum saturated fatty acid}

Tab. 2 shows sorghum saturated fatty acid at after soaking, cooking, germination and fermentation. The results indicted that raw sorghum contains palmitic (12.10$13.41 \%)$, stearic (1.13 to $1.36 \%)$ and arachidic acid (0.10$0.18 \%$ ). 'Shandaweel-6' was the highest variety in palmitic and arachidic acid.

The results are in agreements with Mehmood et al. (2008), who found that sorghum contains palmitic acid (11.73-20.18\%) and stearic acid (1.09-2.59\%). While palmitic acid (11.88-14.18\%), stearic acid (1.09-1.64\%) and arachidic acid (0.12-0.33\%) were present in the grain oil of different sorghum varieties (Pontieri, 2011). In addition, sorghum oil contains $10.90 \%$ palmitic and $2.70 \%$ stearic acid (Adeyeye and Ajewole, 1992). While Asiedu et al. (1993), found that sorghum oil contains palmitic acid (13.2\%), stearic acid (1.30\%) and arachidic acid (0.20\%).

Tab. 2. Sorghum saturated fatty acid at different treatments (\% of total oils)

\begin{tabular}{cccc}
\hline Treatments & C16:0 & C18:0 & C20:0 \\
\hline \multicolumn{4}{c}{ Raw } \\
'Dorado' & $13.14 \pm 0.10^{\mathrm{g}}$ & $1.31 \pm 0.01^{\mathrm{h}}$ & $0.15 \pm 0.01^{\mathrm{cf}}$ \\
'Shandaweel-6' & $13.41 \pm 0.01^{\mathrm{f}}$ & $1.36 \pm 0.02^{\mathrm{g}}$ & $0.18 \pm 0.01^{\mathrm{cd}}$ \\
\hline 'Giza-15' & $12.10 \pm 0.10^{\mathrm{jk}}$ & $1.13 \pm 0.01^{\mathrm{i}}$ & $0.10 \pm 0.01^{\mathrm{g}}$ \\
\hline \multicolumn{4}{c}{ Soaking } \\
'Dorado' & $12.96 \pm 0.04^{\mathrm{h}}$ & $1.35 \pm 0.01^{\mathrm{g}}$ & $0.17 \pm 0.02^{\mathrm{de}}$ \\
'Shandaweel-6 & $13.13 \pm 0.03^{\mathrm{g}}$ & $1.35 \pm 0.01^{\mathrm{g}}$ & $0.17 \pm 0.01^{\mathrm{de}}$ \\
'Giza-15' & $13.06 \pm 0.06^{\mathrm{g}}$ & $1.16 \pm 0.02^{\mathrm{i}}$ & $0.15 \pm 0.01^{\mathrm{cf}}$ \\
\hline \multicolumn{4}{c}{ Cooking } \\
'Dorado' & $12.74 \pm 0.04^{\mathrm{i}}$ & $1.28 \pm 0.02^{\mathrm{h}}$ & $0.19 \pm 0.01^{\mathrm{cd}}$ \\
'Shandaweel-6 & $13.57 \pm 0.03^{\mathrm{c}}$ & $1.53 \pm 0.02^{\mathrm{c}}$ & $0.18 \pm 0.02^{\mathrm{cd}}$ \\
\hline 'Giza-15' & $19.19 \pm 0.01^{\mathrm{a}}$ & $1.89 \pm 0.01^{\mathrm{b}}$ & $0.19 \pm 0.01^{\mathrm{cd}}$ \\
\hline \multicolumn{4}{c}{ Germination } \\
'Dorado' & $14.86 \pm 0.04^{\mathrm{d}}$ & $2.09 \pm 0.01^{\mathrm{a}}$ & $0.20 \pm 0.02^{\mathrm{bc}}$ \\
'Shandaweel-6 & $12.17 \pm 0.02^{\mathrm{j}}$ & $1.74 \pm 0.04^{\mathrm{c}}$ & $0.27 \pm 0.02^{\mathrm{a}}$ \\
\hline 'Giza-15' & $12.07 \pm 0.05^{\mathrm{k}}$ & $1.62 \pm 0.02^{\mathrm{d}}$ & $0.26 \pm 0.02^{\mathrm{a}}$ \\
\hline \multicolumn{4}{c}{ Fermentation } \\
\hline 'Dorado' & $11.22 \pm 0.02^{\mathrm{l}}$ & $1.47 \pm 0.03^{\mathrm{f}}$ & $0.22 \pm 0.02^{\mathrm{b}}$ \\
'Shandaweel-6 & $15.70 \pm 0.02^{\mathrm{b}}$ & $1.65 \pm 0.05^{\mathrm{d}}$ & $0.19 \pm 0.02^{\mathrm{cd}}$ \\
\hline 'Giza-15' & $15.12 \pm 0.02^{\mathrm{c}}$ & $1.91 \pm 0.01^{\mathrm{b}}$ & $0.13 \pm 0.01^{\mathrm{f}}$ \\
LSD & 0.0780 & 0.0378 & 0.0258 \\
\hline
\end{tabular}

Palmitic acid $=\mathrm{C} 16: 0$, stearic acid $=\mathrm{C} 18: 0$ and arachidic acid $=\mathrm{C} 20: 0$. Values are mean of three replicates $\pm \mathrm{SD}$, number in the same column followed by the same letter are not significantly different at $p<0.05$ level 
Tab. 3. Sorghum unsaturated fatty acid at different treatments (\% of total oils)

\begin{tabular}{|c|c|c|c|c|c|}
\hline Treatments & C16:1 & C18:1 & C18:2 & C18:3 & C20:0 \\
\hline \multicolumn{6}{|c|}{ Raw } \\
\hline 'Dorado' & $0.48 \pm 0.02^{\mathrm{c}}$ & $40.34 \pm 0.15^{b c d}$ & $42.58 \pm 0.10^{g}$ & $1.62 \pm 0.02^{f}$ & $0.38 \pm 0.02^{\text {cde }}$ \\
\hline 'Shandaweel-6' & $0.47 \pm 0.01^{\mathrm{c}}$ & $40.15 \pm 0.11^{\mathrm{d}}$ & $42.33 \pm 0.10^{\mathrm{h}}$ & $1.72 \pm 0.01^{\mathrm{dc}}$ & $0.39 \pm 0.02^{\text {cd }}$ \\
\hline 'Giza-15' & $1.31 \pm 0.01^{\mathrm{a}}$ & $33.64 \pm 0.10^{g}$ & $49.94 \pm 0.04^{c}$ & $1.53 \pm 0.02^{\mathrm{g}}$ & $0.24 \pm 0.02^{\mathrm{f}}$ \\
\hline \multicolumn{6}{|c|}{ Soaking } \\
\hline 'Dorado' & $0.50 \pm 0.02^{\mathrm{dc}}$ & $38.68 \pm 0.20^{\mathrm{c}}$ & $44.28 \pm 0.10^{c}$ & $1.68 \pm 0.02^{\mathrm{c}}$ & $0.38 \pm 0.01^{\mathrm{cdc}}$ \\
\hline 'Shandaweel-6' & $0.49 \pm 0.01^{\mathrm{c}}$ & $40.64 \pm 0.12^{\mathrm{ab}}$ & $42.13 \pm 0.03^{\text {hi }}$ & $1.70 \pm 0.01^{\mathrm{c}}$ & $0.38 \pm 0.02^{\text {cde }}$ \\
\hline 'Giza-15' & $0.47 \pm 0.03^{\mathrm{c}}$ & $30.75 \pm 0.20^{\mathrm{i}}$ & $52.15 \pm 0.15^{\mathrm{b}}$ & $1.75 \pm 0.05^{\mathrm{d}}$ & $0.50 \pm 0.02^{\mathrm{b}}$ \\
\hline \multicolumn{6}{|c|}{ Cooking } \\
\hline 'Dorado' & $0.53 \pm 0.01^{\mathrm{cd}}$ & $40.49 \pm 0.30^{\mathrm{bc}}$ & $42.71 \pm 0.20^{g}$ & $1.69 \pm 0.01^{\mathrm{c}}$ & $0.37 \pm 0.01^{\mathrm{de}}$ \\
\hline 'Shandaweel-6' & $0.47 \pm 0.01^{\mathrm{c}}$ & $40.18 \pm 0.13^{\text {cd }}$ & $41.96 \pm 0.04^{\mathrm{i}}$ & $1.69 \pm 0.02^{c}$ & $0.41 \pm 0.01^{c}$ \\
\hline 'Giza-15’ & $0.47 \pm 0.01^{\mathrm{c}}$ & $33.30 \pm 0.10^{\mathrm{h}}$ & $43.15 \pm 0.05^{\mathrm{f}}$ & $1.56 \pm 0.04^{g}$ & $0.35 \pm 0.01^{\mathrm{c}}$ \\
\hline \multicolumn{6}{|c|}{ Germination } \\
\hline 'Dorado' & $0.54 \pm 0.02^{\mathrm{c}}$ & $37.26 \pm 0.11^{\mathrm{f}}$ & $42.69 \pm 0.10^{g}$ & $1.99 \pm 0.01^{\mathrm{a}}$ & $0.36 \pm 0.01^{\mathrm{dc}}$ \\
\hline 'Shandaweel-6' & $0.47 \pm 0.01^{\mathrm{c}}$ & $40.88 \pm 0.10^{a}$ & $42.14 \pm 0.11^{\mathrm{hi}}$ & $1.84 \pm 0.02^{c}$ & $0.51 \pm 0.02^{b}$ \\
\hline 'Giza-15’ & $0.32 \pm 0.02^{\mathrm{g}}$ & $40.37 \pm 0.30^{\mathrm{bcd}}$ & $42.95 \pm 0.05^{\mathrm{f}}$ & $1.91 \pm 0.01^{\mathrm{b}}$ & $0.49 \pm 0.02^{b}$ \\
\hline \multicolumn{6}{|c|}{ Fermentation } \\
\hline 'Dorado' & $0.60 \pm 0.01^{\mathrm{b}}$ & $29.76 \pm 0.11^{j}$ & $54.37 \pm 0.35^{a}$ & $1.99 \pm 0.01^{\mathrm{a}}$ & $0.37 \pm 0.01^{\mathrm{de}}$ \\
\hline 'Shandaweel-6' & $0.38 \pm 0.02^{f}$ & $40.40 \pm 0.22^{\text {bcd }}$ & $39.40 \pm 0.30^{j}$ & $1.61 \pm 0.01^{\mathrm{f}}$ & $0.67 \pm 0.02^{\mathrm{a}}$ \\
\hline 'Giza-15’ & $0.55 \pm 0.03^{c}$ & $30.76 \pm 0.20^{\mathrm{i}}$ & $49.17 \pm 0.10^{\mathrm{d}}$ & $1.87 \pm 0.02^{\mathrm{c}}$ & $0.48 \pm 0.02^{\mathrm{b}}$ \\
\hline LSD & 0.0301 & 0.2823 & 0.2355 & 0.0373 & 0.0279 \\
\hline
\end{tabular}

Palmitoleic acid $=\mathrm{C} 16: 1$, oleic acid $=\mathrm{C} 18: 1$, linoleic acid $=\mathrm{C} 18: 2$, linolenic acid $=\mathrm{C} 18: 3$ and eicosenoic acid $=\mathrm{C} 20: 1$. Values are mean of three replicates \pm SD, number in the same column followed by the same letter are not significantly different at $p<0.05$ level

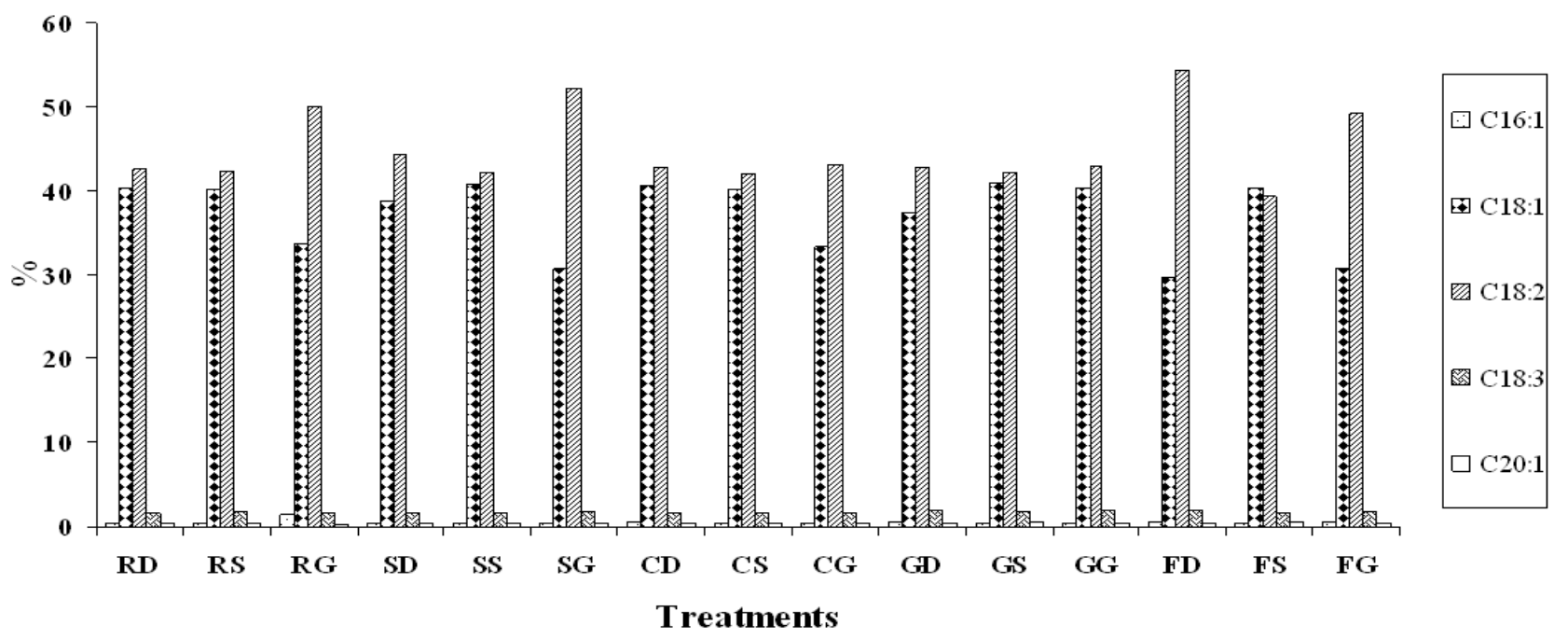

Fig. 2. Unsaturated fatty acids after soaking, cooking, germination and fermentation of sorghum varieties

Treatments: (RD: Raw 'Dorado'; SD: Soaked 'Dorado'; CD: Cooked 'Dorado’; GD: Germinated 'Dorado’; FD: Fermented 'Dorado'; RS: Raw 'Shandaweel-6'; SS: Soaked 'Shandaweel-6'; CS: Cooked 'Shandaweel-6': GS; Germinated 'Shandaweel-6'; FS: Fermented 'Shandaweel-6'; RG: Raw 'Giza-15’; SG: Soaked ‘Giza-15’; CG: Cooked 'Giza-15’; GG: Germinated ‘Giza-15’; FG: fermented 'Giza-15')

\section{Sorghum unsaturated fatty acid}

Tab. 3 and Fig. 2 present sorghum saturated fatty acid after soaking, cooking, germination and fermentation. The results indicted that raw sorghum contains palmitoleic $(0.47-1.31)$, oleic $(33.64-40.35 \%)$, linoleic (42.3349.94\%), linolenic (1.53-1.72\%) and eicosenoic acid (0.24-0.39\%). 'Dorado' was the highest variety in oleic acid. While 'Shandaweel-6' was the highest variety in linolenic and eicosenoic acid and 'Giza-15' was the highest variety in palmitoleic and linoleic. The results are in agreement with previous study, who found that sorghum fatty acid contains palmitoleic acid (0.43-0.56\%), oleic acid (31.12-48.99\%), linoleic acids (27.59-50.73\%) and linolenic acid (1.71-3.89\%) (Mehmood et al., 2008). While 
90

palmitoleic acid (0.42-0.71\%), oleic acid (33.26-43.81\%), linoleic acids (35.51-49.37\%), linolenic acid (1.35-2.14\%) and eicosenoic acid $(0.14-0.52 \%)$ were present in the grain oil of different sorghum varieties (Pontieri et al., 2011).

Percentage of saturated fatty acids (SFA), unsaturated fatty acids (Un SFA) and Un SFA/SFA ratio

Tab. 4 shows percentage of saturated fatty acids (SFA), unsaturated fatty acids (Un SFA) and Un SFA/SFA ratio after soaking, cooking, germination and fermentation. The results indicted that raw sorghum oil contains 13.33 to $14.94 \%$ and 85.06 to $86.67 \%$ of SFA and Un SFA, respectively. 'Shandaweel-6' was the highest variety in SFA. While 'Giza-15' was the highest variety in Un SFA and Un SFA/SFA ratio. Most of sorghum varieties polyunsaturated fatty acids were higher than monounsaturated fatty acids (Mehmood et al., 2008). The white sorghum oil contains $12.40 \%$ total saturated fatty acid and $87.60 \%$ total unsaturated fatty acid, respectively (Hadbaoui et al., 2010). Also, sorghum grains had high degrees of unsaturation (86.4\%) and high quantities of essential fatty acids (58.0\%) compared with the other cereals (Adeyeye and Ajewole, 1992). As the saturated fatty acids increases the risks of cardiovascular diseases, cancer and autoimmune disorders (Iso et al., 2002). Oils being source of lipids, are of more nutritional value if they have more unsaturated to saturated fatty acid ratio (Aronson et al., 2001).

Tab. 4. Percentage of saturated fatty acids (SFA), unsaturated fatty acids (Un SFA) and Un SFA/SFA ratio of sorghum at different treatments

\begin{tabular}{|c|c|c|c|}
\hline Treatments & SFA* & Un SFA** & $\begin{array}{l}\text { Un SFA/ } \\
\text { SFA ratio }\end{array}$ \\
\hline \multicolumn{4}{|c|}{ Raw } \\
\hline 'Dorado' & 14.60 & 85.40 & 5.26 \\
\hline 'Shandaweel-6' & 14.94 & 85.06 & 5.69 \\
\hline 'Giza-15’ & 13.33 & 86.67 & 6.50 \\
\hline \multicolumn{4}{|c|}{ Soaking } \\
\hline 'Dorado' & 14.48 & 85.52 & 5.91 \\
\hline 'Shandaweel-6 & 14.66 & 85.34 & 5.82 \\
\hline 'Giza-15’ & 14.37 & 85.63 & 5.96 \\
\hline \multicolumn{4}{|c|}{ Cooking } \\
\hline 'Dorado' & 14.22 & 85.78 & 6.03 \\
\hline 'Shandaweel-6' & 15.28 & 84.72 & 5.54 \\
\hline 'Giza-15’ & 21.28 & 78.72 & 3.70 \\
\hline \multicolumn{4}{|c|}{ Germination } \\
\hline 'Dorado' & 17.15 & 82.85 & 4.83 \\
\hline 'Shandaweel-6' & 14.18 & 85.82 & 6.05 \\
\hline 'Giza-15’ & 13.95 & 86.05 & 6.17 \\
\hline \multicolumn{4}{|c|}{ Fermentation } \\
\hline 'Dorado' & 12.92 & 87.08 & 6.74 \\
\hline 'Shandaweel-6' & 17.55 & 82.45 & 4.70 \\
\hline 'Giza-15’ & 17.16 & 82.84 & 4.83 \\
\hline
\end{tabular}

${ }^{*} \mathrm{SFA}=$ Saturated fatty acids. ${ }^{* *} \mathrm{Un} \mathrm{SFA}=$ Unsaturated fatty acids
The fat in sorghum grain (mainly present in the germ) is rich in polyunsaturated fatty acids (Glew et al., 1997). The fatty acid composition of sorghum fat (linoleic acid $49 \%$, oleic $31 \%$, palmitic $14 \%$, linolenic $2.7 \%$, stearic $2.1 \%$, etc.) is similar in content to that of corn oil, but it is more unsaturated (Adeyeye and Ajewole, 1992; FAO, 1995; Knudsen et al., 1988). Sorghum is a good source of carotene, vitamins, notably the B vitamins (thiamin, riboflavin, pyridoxine, etc.), and the lipid soluble vitamins A, D, E and K (Anglani, 1998; Afify et al., 2012a).

In addition, sorghum oil contains $28.40 \%$ oleic acid, $50.90 \%$ linoleic acid and $7.11 \%$ linolenic acid (Adeyeye and Ajewole, 1992). While Asiedu et al. (1993), found that sorghum oil contains palmitoleic acid $(0.50 \%)$, oleic acid (41.20\%), linoleic acids (40.10\%), linolenic acid (3.0 $\%)$ and eicosenoic acid (0.20\%).

The oil levels of sorghum varieties decreased on germination, cooking and fermentation. The observed decrease might be due to the increased activities of the lipolytic enzymes during germination and fermentation, which hydrolyse oils to fatty acids and glycerol (Raham and Aal, 1986). The simpler products can be used for synthesis of carbohydrate and protein or as a source of energy for developing embryo. Similar observation was made by other researchers (Obizoba and Atti, 1994; Nnam, 2000). In addition, reduced oil contents in malted millet for "Ogi) production and low lipid levels are known to increase shelf-life (Inyang and Idoko, 2006). Fermentation has also been strongly suggested to have inhibitory effects on the groups of micro-organisms that can cause spoilage or food poisoning (Odumodu and Inyang, 2006).

Germination induces the synthesis of hydrolytic enzymes, e.g. starch degrading enzymes, and proteases and phytases. Phytate content was significantly reduced from 23.59 to $32.40 \%$ for soaking treatment and 24.92 to $35.27 \%$ for germination treatments, respectively (Afify $e t$ al., 2011a).

The reduction of phytic acid, flavonoids, tannine and phenolic acid and proanthocyanidins has been observed during germination and soaking (Afify et al., 2012a; FAO, 1995; Traoré et al., 2004). Germination of sorghum is important for the preparation of weaning foods with low paste viscosity and high energy density (Malleshi and Desikachar, 1988). Lipids mainly present in the germ and more unsaturated than in corn fatty acid composition and considered similar to corn, with linoleic (49\%), oleic (31\%), and palmitic acid (14\%) (Glew et al., 1997).

\section{Conclusions}

Vegetable oil not only provides high quality food, containing essential nutrients for the life, but also bioactive compounds that have particular clinical significance. Sorghum is worth attention as a source of health promoting component for foods. Fatty acids with some pharmacological significance have caught the attention of both 
consumer and industries. Raw sorghum oil contains 13.33 to $14.94 \%$ and 85.06 to $86.67 \%$ of SFA and Un SFA, respectively. 'Dorado' was the highest variety in oil content. After germination, oil content was decreased. 'Dorado' was the highest variety in oleic acid. While 'Shandaweel-6' was the highest variety in palmitic, stearic, linolenic, arachidic, eicosenoic acid and total saturated fatty acids. 'Giza-15' was the highest variety in palmitoleic, linoleic, total unsaturated fatty acids and unsaturated to saturated fatty acids ratio. Most of fatty acids percentage changed after different treatments. Sorghum bicolor varieties could be additional sources of edible oil due to presence of clinically important saturated and high concentration of unsaturated fatty acids.

\section{Acknowledgments}

Authors would like to thank the management of the Faculty of Agriculture, Cairo University and Technology Research Institute, Agricultural Research Center for ongoing cooperation to support research and providing funds and facilities necessary to achieve the desired goals of research.

\section{References}

Abdel-Rahim EA, El-Beltagi HS (2010). Constituents of apple, parsley and lentil edible plants and their therapy treatments for blood picture as well as liver and kidneys functions against lipidemic disease. Electron J Environ, Agricult Food Chem 9:1117-1127.

Adeyeye A, Ajewole K (1992). Chemical composition and fatty acid profiles of cereals in Nigeria. Food Chem 44:41-44.

Afify AMR, El-Beltagi HS, Abd El-Salam SM, Omran AA (2011a). Bioavailability of iron, zinc, phytate and phytase activity during soaking and germination of white sorghum varieties. PLoS ONE 6(10):e25512, 1-7.

Afify AMR, Rashed MM, Ebtesam AM, El-Beltagi HS (2011b). Effect of gamma radiation on protein profile, protein fraction and solubility of three oil seeds. Not Bot Horti Agrobo 39(2):90-98.

Afify AMR, El-Beltagi HS, Hammama AA, Sidky MMA, Mostafa OFA (2011c). Distribution of trans-anethole and estrasgole in fennel (Foeniculum vulgare Mill) of callus induced from different seedling parts and fruits. Electron J Environ, Agricult Food Chem 10(2):1897-1908.

Afify AMR, El-Beltagi HS, Abd El-Salam SM, Omran AA (2012a). Biochemical changes in phenols, flavonoids, tannins, vitamin $E, \beta$-carotene and antioxidant activity during soaking of three white sorghum varieties. Asian Pacific J Tropical Biomed 2(3):203-209.

Afify AMR, El-Beltagi HS, Abd El-Salam SM, Omran AA (2012b). Protein solubility, digestibility and fractionation after germination of sorghum varieties. PLoS ONE 7(2) e31154.

Alemu MK (2009). The Effect of Natural Fermentation on Some Antinutritional Factors, Minerals, Proximate Com-
91

position and Sensory Characteristics in Sorghum Based Weaning Food. M.Sc. Thesis, Addis Ababa University, Addis Ababa, Ethiopia, 83 p.

Anglani C (1998). Sorghum for human food: A review. Plant Foods Hum Nutr 52:85-89.

AOAC (2000). Official Methods of Analysis of the Association of Official Analytical Chemists, $17^{\text {th }}$ Edn (edited by W. Horwitz) Washington, DC.

Aronson WJ, Glaspy JA, Reddy ST, Reese D, Heber D, Bagga J (2001). Modulation of omega-3/omega-6 polyunsaturated ratios with dietary fish oils in men with prostate cancer. Urology 58:283-288.

Asiedu M, Nilsen R, Lie O, Lied E (1993). Effect of processing (sprouting and/or fermentation) on sorghum and maize. I:proximate composition, minerals and fatty acids. Food Chem 46:351-353.

Chung M, Kim E, Yeo M, Kim S, Seo M, Moon H (2011). Antidiabetic effects of three Korean sorghum phenolic extracts in normal and streptozotocin-induced diabetic rats. Food Res Int 44:127-132.

Dicko MH, Gruppen H, Traoré AS, Voragen AGJ, van Berkel WJH (2006). Sorghum grain as human food in Africa: relevance of content of starch and amylase activities. Afr J Biotech 5(5):384-395.

Dillon SL, Shapter FM, Henry RJ, Cordeiro G, Izouierdo L (2007). Domestication to crop improvement:genetic resources for sorghum and saccharum (Andropogoneae). Ann Bot 100(5):975-989.

El-Beltagi HES, Mohamed AA (2010). Variation in fatty acid composition, glucosinolate profile and some phytochemical contents in selected oil seed rape (Brassica napus L.) cultivars. Fats oil, Grasas y Aceites 61(2):143-150.

El-Beltagi HS (2011). Effect of roasting treatments on protein fraction profiles, some enzyme activities of Egyptian peanuts. Inter J Food Sci Nutr 62(5):453-456.

El-Beltagi HS, Mohamed AA, Mekki BB (2011a). Differences in some constituents, enzymes activity and electrophoretic characterization of different rapeseed (Brassica napus L.) cultivars. Ann Univ Oradea-Fascicle Biol Tom 18(1):39-46.

El-Beltagi HS, Salama ZA, El-Hariri DM (2011b). Variations in oil and some phytochemical contents in flaxseed cultivars (Linum usitatissimum L.). Electron J Environ, Agricult Food Chem 10(8):2711-2721.

El Maki HB, Abdel Rahaman SM, Idris WH, Hassan AB, Babiker EE, EL Tinay AH (2007). Content of antinutritional factors and $\mathrm{HCl}$-extractabitity of minerals from white bean (Phaseolus vulgaris) cultivars:Influence of soaking and/or cooking. Food Chem 100:362-368.

Food and Agricultural Organization-FAO (1995). Sorghum and millet in human nutrition. FAO Food and Nutrition Series No. 27. Consulted on 10 September 2005 at:http://www. fao.org/DOCREP/T0818e/T0818E00.htm\#Contents.

Glass RL (1971). Alcoholysis, saponification and the preparation of fatty acid methyl esters. Lipids 6(12):919-925. 
92

Glew RH, Vanderjagt DJ, Lockett C, Grivetti LE, Smith GC, Pastuszyn A, Millson M (1997). Amino acid, fatty acid, and mineral composition of 24 indigenous plants of Burkina Faso. J Food Compos Anal 10:205-217.

Hadbaoui Z, Djeridane A, Yousfi M, Saidi M, Nadjemi B (2010). Fatty acid, tocopherol composition and the antioxidant activity of the lipid extract from the sorghum grains growing in Algeria. MJNM 3:215-220.

Hamad RME (2007). Preliminary Studies on the Popping Characteristics of Sorghum Grains. M.Sc. Thesis, Sudan Academy of Science, Al-Zaiem Al-Azhari Univiversity, Sudan, 90 p.

Hoseney RC, Varriano-Marston E, Dendy DAV (1981). Sorghum and millets. Anatomy, composition, milling. Adv Cereal Sci Technol 4:71-144.

Inyang CU, Idoko CA (2006). Assessment of the quality of "ogi" made from malted mallet. Afr J Biotechnol 5:2334-2337.

Iso H, Sato S, Umemura U, Kudo M, Koike K, Kitamura A, Imano H, Okamura T, Naito Y, Takaski S (2002). Linoleic acid, other fatty acids, and the risk of stroke. Stroke 33:20862093.

Knudsen BKE, Munck L, Eggum BO (1988). Effect of cooking $\mathrm{pH}$ and polyphenol level on carbohydrate composition and nutritional quality of sorghum (Sorghum bicolor (L.) Moench) food, ugali. British J Nutr 59:31-47.

Lonnerdal B (2000). Dietary factors influencing zinc absorption. J Nutr 130:1378S-1383S.

Malleshi NG, Desikachar HSR (1988). Reducing the paste viscosity (dietary bulk) of roller dried weaning foods using malt or fungal amylase. J Food Sci Technol 25:1-3.

Matz SA (1991). The Chemistry and Technology of Cereals as Food and Feeds. $2^{\text {nd }}$ edn. Van Nostrand, Rcinhold, New York, $187 \mathrm{p}$.

Mehmood S, Orhan I, Ahsan Z, Aslan S, Gulfraz M (2008). Fatty acid composition of seed oil of different Sorghum bicolor varieties. Food Chem 109:855-859.

Morrison WR (1978). Cereal lipids. Adv Cereal Sci Technol 2:221-348.

Mubarak AE (2005). Nutritional composition and antinutritional factors of mung bean seeds (Phaseolus aureus) as affected by some home traditional processes. Food Chem 89:489-495.

Nnam NM (2000). Evaluation of effect of sprouting on the viscosity, proximate composition and mineral content of hungary rice, acha (Digiteria exilis) flours. Nig Food J 18:57-62.

Obizoba IC, Atti JV (1994). Evaluation of the effect of processing techniques on the nutrient and anti nutrient contents of pearl millet (Pennisetum glaucum) seeds. Plant Foods Hum Nutr 45:23-24.
Odumodu CU, Inyang CU (2006). Effects of fermentation on microbial loads of formulated complementary food. Ann Microbiol 56:331-334.

Okrah SG (2008). Screening of Six Local Sorghum Varieties for their Malting and Brewing Qualities. MSc. Thesis, Kwame Nkrumah University Science and Technology, Ghana, 87p.

Osagie AU (1987). Total lipids of sorghum grain. J Agric Food Chem 35:601-604.

Palmer GH, Etokakpan OU, Igyor MA (1989). Review: sorghum as brewing material. World J Microbil Biotechnol 5:265-275.

Patil V, Gislerød HR (2006). The importance of omega-3 fatty acids in diet. Current Sci 90(7):908-909.

Pontieri P, Di Fiore R, Troisi J, Bean SR, Roemer E, Okot J, Alifano P, Pignone D, Giudice LD, Massardo DR (2011). Chemical composition and fatty acid content of white food sorghums grown in different environments. Maydica 56:1-7.

Raham EH, Aal MH (1986). Changes in gross chemical composition with emphasis on lipid and protein fractions during germination of fenugreek seeds. Food Chem 22:193-198.

Shallan MA, El-Beltagi HS, Mona A, Amera TM, Sohir NA (2010a). Effect of amylose content and pre-germinated brown rice on serum blood glucose and lipids in experimental animal. Austr J Appl Sci 4:114-121.

Shallan MA, El-Beltagi HS, Mona A, Amera TM (2010b). Chemical Evaluation of Pre-germinated Brown Rice and Whole Grain Rice Bread. Electron J Environ, Agricult Food Chem 9:958-971.

Shallenbcrger JA (1971). Wheat chemistry and technology. In: Pomenanz Y (Ed.). $2^{\text {nd }}$ Edition. American Association of Cereal Chemists, 1-8 p.

Shehab GG, Kansowa OA, El-Beltagi HS (2010). Effects of various chemical agents for alleviation of drought stress in Rice plants (Oryza sativa L.). Not Bot Horti Agrobo 38:139148.

Traoré T, Mouquet C, Icard-Verniere C, Traore AS, Treche S (2004). Changes in nutrient composition, phytate and cyanide contents and $\alpha$-amylase activity during cereal malting in small production units in Ouagadougou (Burkina Faso). Food Chem 88:105-114.

Zhao R, Bean SR, Ioerger BP, Wang D, Boyle DL (2008). Impact of mashing on sorghum proteins and its relationship to ethanol fermentation. J Agric Food Chem 56(3):946-953. 